\title{
The Role of Midwives in Overcoming Labor Pain
}

\author{
$1^{\text {st }}$ Rina Nursanti \\ Department of Midwifery \\ Poltekkes Kemenkes Palembang \\ Palembang, Indonesia \\ rinanursanti@poltekkeskemenkespalembang.ac.id
}

\author{
$2^{\text {nd }}$ Eprila \\ Department of Midwifery \\ Politeknik Kesehatan Palembang \\ Palembang, Indonesia \\ eprila@poltekkeskemenkespalembang.ac.id
}

Corrresponding author: rinanursanti@ poltekkeskemenkespalembang.ac.id

\begin{abstract}
Almost all women who gave birth, had experienced severe pain during labor and this is a normal thing to happen. The pain experienced during childbirth is different for each mother. Therefore, in dealing with labor pain between one mother to another, will experience differently. By the concept of Women Centered Care, the choice of pain relief for each mother is different, the nurse only facilitates it. The pain management must utilize the competence of existing midwives by the results of research that has been done (evidence-based midwifery). This study aims to obtain information on how the role of midwives in dealing with labor pain based onevidence- based midwifery based on the philosophy of women-centred care. This study uses a qualitative method with a phenomenological approach. Sources of data obtained from informants through observation, in-depth interviews, field notes, and documentation. To maintain the validity of the data, the researchers triangulate sumber and triangulation techniques. The results of the research from three informants showed that there were differences in the application of pain management that had been given to mothers in labor. Two of the three informants have carried out labor pain management based on evidence-based midwifery based on the philosophy of women- centred care.
\end{abstract}

Keywords: The role of the midwife, pain labor

\section{INTRODUCTION}

According to Permenkes No. 1464 / Menkes / Per / IX / 2010, article 1 paragraph 1 . A midwife is a woman who has graduatedfrom a registered midwife education by statutory provisions [1]. Concerning midwifery services, midwifery is formed from various disciplines of medicine, nursing science, social science, behavioral science, cultural science, public health science, and management science [2]. Midwives, in carrying out health care and midwifery in the community, is authorized by the government as outlined in the Decree No. 1464 / Menkes / Per / X / 2010 on the licensing and operation of the nursing practicum. One of the authorities possessed by midwifery is to provide normal delivery care [1].

The International Confederation of Midwifery (ICM) states that midwives must be consistent in implementing the philosophy of midwifery care, which is to believe that women experience natural and normal reproductive processes. Based on this philosophy, midwives play a role in ensuring the natural process of women's reproduction with a focus on women-centered care in a sustainable manner (Continuity of Care). So that amidwifery was given a comprehensive, independent and responsible and sustainable throughout the life cycle f women [3].

Almost all mothers feel labor pain and this is a physiological thing that is influenced by psychological conditions of anxiety and fear. Feelings of anxiety and fear cause the blood vessels to constrict, which can block blood flow throughout the body and decrease. This will greatly affect the function of the organs involved in childbirth to not function properly. The power to push becomes less strong, the push from the body is also not strong so that it hinders the delivery process [4]. According to Andarmoyo \& Suharti (2013), pain during childbirth is a manifestation of the contraction (approach) of the uterine muscles. This contraction causes pain in the waist, abdominal area and radiates towards the thigh. These contractions 
cause the opening of the cervix (cervix). With this cervical opening, labor will occur. The pain experienced during childbirth is unique to each mother, which can be influenced by sever alfactors, including culture, fear, anxiety/fear, previous labor experiences, and support [5].

Almost all mothers feel labor pain and this is a physiological thing that is influenced by psychological conditions of anxiety and fear. Feelings of anxiety and fear cause the blood vessels to constrict, which can block blood flow throughout the body and decrease. This will greatly affect the function of the organs involved in childbirth to not function properly. The power to push becomes less strong, the push from the body is also not strong so that it hinders the delivery process [4].

According to Andarmoyo \& Suharti (2013), pain during childbirth is a manifestation of the contraction (approach) of the uterine muscles. This contraction causes pain in the waist, abdominal area and radiates towards the thigh. These contractions cause the opening of the cervix (cervix). With this cervical opening, labor will occur. The pain experienced during childbirth is unique to each mother, which can be influenced by several factors, including culture, fear, anxiety/fear, previous labor experiences, and support [5].

One of the most accepted and reliable theories of pain is the Gate control theory. Experts in the field of obstetrics also adhere to this gate control theory to explain pain in labor. Thefirst rationale for gate control theory is that the existence and intensity of pain experiences depend on specific transmissions of nerve impulses. Second, the gate mechanism throughout the nervous system controls or controls the eventual transmission of pain. If the gate is open, the impulses that cause the pain sensation can reach the level of consciousness. If the gate is closed, the impulse does not reach the level of consciousness and the pain sensation is not experienced. The indicator for the presence of the most pain intensity is the mother's report of the pain itself. However, pain intensity can also be determined in various ways, one of which is to ask the mother to describe the pain or discomfort [6].

Labor pain can cause anxiety and fear in patients so that oxygen demand increases, muscles become tense and blood pressure increases, this situation will stimulate catecholamines which can cause interference with the strength of contractions resulting in prolonged labor [7]. Handling and monitoring of labor pain, especially during the first stage of the active phase, is very important because this is a determining point whether a woman in labor can undergo normal labor or terminate an action due to complications caused by very severepain [8].

According to Walsh (2007), if the pain is not handled properlyit can cause other problems, namely increasing anxiety when facing childbirth so that adrenaline hormone production increases and results in vasoconstriction which causes maternal blood flow to the fetus [9]. Decreased blood flowand oxygen to the uterus and tissue ischemia result in the fetus experiencing hypoxia and the mother will take a long labor process and cause more pain impulses. Therefore, it can increase the amount of maternal and neonatal morbidity [10].

Various attempts were made to deal with labor pain. Usually, ways to deal with labor pain are divided into pharmacological and non-pharmacological ways. The pain experienced by each individual is different and will come slowly and will peak at the last seconds of labor. Some are strong enough to face it, some are not strong enough to face it. For patients or mothers who feel unbearable pain and can interfere with the delivery process. Pharmacological methods are more expensive, also have the potential to have adverse effects while non- pharmacological methods are cheaper, simpler, effective, without adverse effects and can increase satisfaction during labor because the mother can control her feelings and strength[11].

The non-pharmacological management of labor pain has several advantages over pharmacological pain management if adequate pain control measures are provided. Several non- pharmacological techniques that can increase comfort in facing the labor process are relaxation, breathing techniques, movement and position changes, massage, hydrotherapy, music, hypnobirthing, ater birth [10].

\section{RESEARCH METHODOLOGY}

This study used a qualitative method, intending to obtain in- depth and objective information about the role of midwives in overcoming labor pain. This research was conducted in April -December 2018 at the Practice of Midwives (PMB) "L" Perumahan Talang Kelapa. The informant in this study was the midwife ' $\mathrm{L}$ ' who was implementing PMB. The data collection techniques in this study used the method of observation, interviews, field notes, and documentation. In this study, researchers conducted indepth interviews with informants about maternal care, starting from the time the patient arrived until 2 hours after delivery. Observation aims to observe informants in overcoming labor pain in mothers who givebirth.

As a complementary data collection technique, the 
recording was performed. The recording device is used as evidence of the information retrieval process as research data. Besides, recording devices can be used to help process data more easily. Analysis of data $\mathrm{p}$ No research is how to analyze the ongoing process of a social phenomenon and obtain a complete picture of the process [12].

Analytical research was based oninterviews and observations at the informant during labor pain management in deliveringmothers. Presentation of data in this study is in the form of narrative text and for observations in the form of pictures or photos in the appendix.

\section{RESULTS AND DISCUSSION}

\section{A. Characteristics of Informants}

Informants were used in this research is midwife "L" was born in Palembang on 10 January 1982. Midwife "L" graduated midwives in Kader Bangsa Midwifery Academy in 2000. After graduating from education, midwife open clinical practice independently in Talang Kelapa area. While doing independent practice, the midwife already has STR and is granted a license to practice. The midwife's independent practice has one delivery room with one bed, one treatment room with three beds, one examination room with one bed.

\section{B. Application of Labor Pain Management}

Based on the results of interviews and observations of informants, it is known that the implementation of labor pain management in independent practice uses non- pharmacologicalpain management methods. Some of the non- pharmacological labor pain management techniques used are:

1) A distraction technique by focusing on the patient's attention on something other than pain such as listening to music.

2) Massage technique, which is doing hand pressureon soft tissue usually in the area of the pelvic muscles or on the ligaments without causing movement or changing the position of the joint to relieve pain.

3) Breathing relaxation techniques by teaching the patient to inhale a deep inhalation from the nose slowly and exhaling slowly from the mouth.

C. Application of labor pain management based on the philosophy of woman-centred care.
Based on field observations made by researchers in assisting informants in helping with childbirth, it can be concluded that the informants have not yet carried out labor pain management based on the philosophy of woman-centred Care. Because in dealing with labor pains, theinformant did the same to all mothers who gave birth, namely utilizing breathing relaxation, distraction and encouraging the patient's family/husband to do a light massage in the patient's abdomen and waist without giving the mother the opportunity or choice of what the priorities were. in dealing with labor pain.

D. Application of labor pain management based on the philosophy of woman-centred care.

Based on field observations made by researchers in assisting informants in helping with childbirth, it can be concluded that the informants have not yet carried out labor pain management based on the philosophy of woman-centred Care. Because in dealing with labor pains, theinformant did the same to all mothers who gave birth, namely utilizing breathing relaxation, distraction and encouraging the patient's family/husband to do a light massage in the patient's abdomen and waist without giving the mother the opportunity or choice of what the priorities were. in dealing with labor pain.

E. Application of labor pain management based on the philosophy of woman-centred care.

Based on field observations made by researchers in assisting informants in helping with childbirth, it can be concluded that the informants have not yet carried out labor pain management based on the philosophy of woman-centred Care. Because in dealing with labor pains, theinformant did the same to all mothers who gave birth, namely utilizing breathing relaxation, distraction and encouraging the patient's family/husband to do a light massage in the patient's abdomen and waist without giving the mother the opportunity or choice of what the priorities were. in dealing with labor pain.

\section{DISCUSSION}

Almost all mothers experience intense pain during labor, and this is normal. The psychological condition of anxiety and fear is a factor that affects pain which greatly affects the bodily functions physically. Pain is a personal experience, subjective, different from one person to another and can also be different in the same person at different times. Various attempts were made 
to reduce pain during labor, both pharmacologically and non Pharmacologically. Pharmacological pain management is more effective than nonpharmacological methods, but pharmacological methods are more expensive, and potentially have unfavourable effects. Meanwhile, non-pharmacological methods arecheap, simple, effective, and without any adverse effects. Non- pharmacological methods can also increase satisfaction during childbirth because the mother can control her feelings and strengths [13].

The implementation of labor pain management by the informants was still limited using distraction, massage and breathing relaxation techniques. Massage techniques can stimulate the body to release endorphins, which are natural painkillers and stimulate the production of the hormone oxytocin, reduce stress hormones, and neurological stimulation [14].

This is following a study conducted by Fatmala \& Astuti (2017) which obtained an average result of labor pain intensity given back massage decreased from 6.13 before the intervention and 4.56 after intervention [15].

When a person listens to music when he is in pain, the brain will receive music impulses first rather than pain impulses, so that music can provide distraction or diversion or reduction in the concentration of pain [5]. The results of research from Astuti, Rahayu \& Mulyani (2016) found that there was a decrease in the average intensity of pain from 7.13 to 4.88 and a decrease in the average intensity of pain behaviour from 6.72 to 2.66 after instrumental music therapy [16]. This is in line with research by Fatmala \& Astuti (2017) which explains that the average labor pain intensity before the intervention was 6.63 , which decreased to 5.47 after being given classical music therapy [15].

Apart from reducing pain intensity, breathing relaxation techniques can also improve pulmonary ventilation and increase blood oxygenation [17]. According to the usefulness of the breathing relaxation technique, it is considered to be able to relieve pain, the process is to breathe slowly through the nose (hold the inspiration to the maximum) and exhale through the mouth slowly [18]. Researcher Yuksel, Cayir, Kosan and Tastan (2017) tested the maternal breathing exercises on the second stage and found that the intervention group had lower pain intensity compared with the control group [19].
In providing care for mothers who give birth, Informa has not used a mother-centred pain approach. The philosophy of midwifery care is to believe that the female reproductive process is a natural and normal process experienced by every woman. Midwives in providing care must partner with women, give authority to women, care individually, care continuously and sustainably, practice autonomously, and practice evidence- based care [20].

\section{CONCLUSION}

The role of midwives in overcoming labor pain was carried out by the informants using nonpharmacological techniques, namely distraction, massage and breathing relaxation techniques. Management of labor pain non- pharmacologic besides easy to do also have fewer side effects with lower cost. However, in practice, the informants have not done pain management based on woman-centred care.

\section{ACKNOWLEDGMENT}

The author is grateful to the Palembang Health Polytechnic Institution through the Center for Research and Community Service for mentoring andfunding with a beginner lecturer research scheme in 2020 .

\section{REFERENCES}

[1] Decree Of The Minister Of Health Of The Republic Of Indonesia. No Title. Indonesia: 2010.

[2] Midwifery Concepts And Ethicolegal Practice Of Midwifery 2010.

[3] Power I, Toothpaste OF, Kencur C. 2 Nd International Conference On Applied Science And Health ( KAEMPFERIA GALANGA ) TO THE GROWTH OF STREPTOCOCCUS 2 $\mathrm{Nd}$ International Conference On Applied Science And Health N.D.:286-91.

[4] Reeder, SJ, LL Martin And DK-G. Maternity Nursing: Family, Newborn, And Women's Health Care, Transfer Language Yati Afiyanti,Imami Nur Rachmawati Andsri Djuwitaningsi "Maternity Nursing: Women's, Infant \& Family Health 2011.

[5] Andarmoyo, Suharti And SS. Labor Without Excessive Pain, 2013.

[6] Mahmoud R, Ghani A, Shaaban A, Elmonem A. Effect Of Olive Oil Massage On Postoperative Cesarean Pain And Sleep Quality: A Randomized Controlled Trial Effect Of Olive Oil Massage On Postoperative Cesarean Pain And Sleep Quality: A Randomized Controlled Trial. IOSR J Nurs Heal Sci 2018;7:92-8. Https://Doi.Org/10.9790/19590702099298.

[7] Melinda Eka Anggraeni. Overview Massage Against Reduction Flavor Painful Childbirth Kala I Phase Active In Bpm Ny. Yenie Ika Sugiarti, S. St. Bakalan Gondang Mojokerto. 2015.

[8] Forejt V, Kwiatkowska M, Norman G, Parker D. Automated Verification Techniques For Probabilistic Systems. Lect Notes Comput Sci (Including Subser Lect Notes Artif Intell Lect Notes Bioinformatics) 2011;6659LNCS:53-113. Https://Doi.Org/10.1007/978-3-642-21455-4 3. 
[9] Wailsh L V. Books Teach Midwifery Community. EGC. Jakarta: 2007.

[10] Sumarah, YN, Y. Widyastuti And NW. Midwifery Care For Mother Inlabor. Jyogyakarta: 2008.

[11] Maryunani A. Pain In Labor Techniques And Ways Of Handling It. Jakarta: 2010.

[12] Burhan BH. Qualitative N.D.

[13] Research Seconf Edition. No Ti. Jakarta: 2011.

[14] Herawati R. Evaluation Of The Most Effective Relaxation Techniques In The Management Of Stage I Labor Pain Againt Succesful Normal Deliver. J Marternityand Neonatal 22 2016:102-13.

[15] Chauhan, Kamini, Seema Rani And PB. Effectiveness Of Olive Oil Back Massage On Reduction Of Labor Pain During First Stage Of Labor 2016:2-3.

[16] Astuti, KH Endah Widhi, RD Rahayu And NHSM. Effects Of Therapy Musicinstrumental Against Decrease In Intensity Of Pain Childbirth Kala I Active In 3 Midwife Practices Self Ngemplak Boyolali. J Midwifery Tradit Heal 2016.

[17] Brunner, Suddarth And DS. Books Teach Nursing MedicalSurgical. Jakarta: 2002.

[18] Meiliasari,M. And BD. Maternity Normal Without Sense Of Pain. Jakarta: 2004.

[19] Yuksel H, Cayir Y, Kosan Z, Tastan K. Effectiveness Of Breathing Exercises During The Second Stage Of Labor On Labor Pain And Duration: A Randomized Controlled Trial. J Integr Med 2017;15:456- 61. Https://Doi.Org/10.1016/S20954964(17)60368-6.

[20] Jain CK, Bhatia KKS, Kumar CP, Purandara BK. Philosophy And Model Of Midwifery Care Background. Indian J Environ Prot 2003;23:321-9. 